Journal of Southeast Asian

\title{
Book Review: Duran, C. S. (2017). Language and Literacy in Refugee Families. United Kingdom: Palgrave MacMillan.
}

Minjung Ryu

Purdue University, mryu@purdue.edu

Follow this and additional works at: https://docs.lib.purdue.edu/jsaaea

Part of the Bilingual, Multilingual, and Multicultural Education Commons, and the Language and Literacy Education Commons

\section{Recommended Citation}

Ryu, Minjung (2019) "Book Review: Duran, C. S. (2017). Language and Literacy in Refugee Families. United Kingdom: Palgrave MacMillan.," Journal of Southeast Asian American Education and Advancement: Vol. 14 : Iss. 1, Article 2.

DOI: $10.7771 / 2153-8999.1170$

Available at: https://docs.lib.purdue.edu/jsaaea/vol14/iss1/2

This document has been made available through Purdue e-Pubs, a service of the Purdue University Libraries. Please contact epubs@purdue.edu for additional information.

This is an Open Access journal. This means that it uses a funding model that does not charge readers or their institutions for access. Readers may freely read, download, copy, distribute, print, search, or link to the full texts of articles. This journal is covered under the CC BY-NC-ND license. 


\title{
ISAAEA Journal of Southeast Asían American Education and Advancement
}

Vol. 14 Iss. 1 (2019)

\author{
WWW.JSAAEA.org
}

Book Review: Duran, C. S. (2017). Language and Literacy in Refugee Families. United Kingdom, UK: Palgrave MacMillan. 226 pp. ISBN: 978-1-137-58754-1.

\author{
Reviewed by \\ Minjung Ryu \\ Purdue University
}

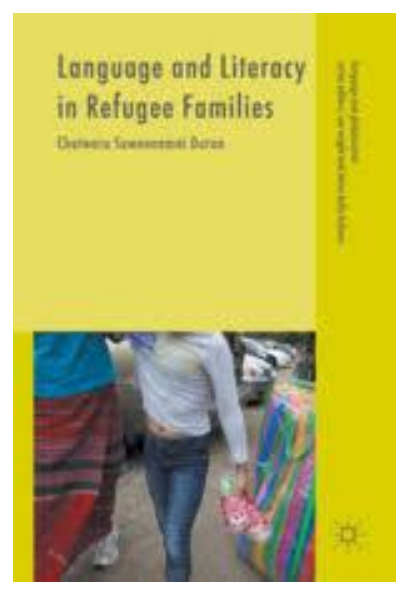

The dominant narrative about refugees and resettled refugees in the United States depicts them as helpless victims who have fled from lifethreatening living conditions in their countries of origin, do not have the skills nor inclination needed to either support themselves or integrate into their host country, and consequently become a fiscal and social burden for their new neighbors. Even among scholars, refugee youth, as students, are often described as English language learners (ELLs) whose English proficiency is limited, students with interrupted formal education (SIFE) who do not have necessary background knowledge to succeed in education system in the United States, and those in need of mental health support due to trauma incurred in transit to their host communities. Nobody disputes the unique disadvantages and challenges such students and their families face. To a certain extent, these negative characterizations are deployed and reproduced to solicit funding and donations to mitigate hurdles in the resettlement process. However, these narratives of deficiency, lack, and debilitating trauma are also all too often inaccurate and disempowering in that they strip agency from resettled refugees and disregard the rich cultural and linguistic resources they bring for their own self-sufficiency and, consequently, to the host society itself. The way in which refugees are an asset to a host community are largely muted by these dominant narratives in both the mainstream and in academia. Chatwara Suwannamai Duran's book Language and Literacy in Refugee Families addresses this dilemma by showing the experience of three Karenni families who fled from their homelands in Myanmar (formerly Burma). Rather than focusing on tropes of trauma, Duran reveals the rich home-based language and literacy practices that inform and sustain these remarkable, but exemplary families.

Duran begins her study with a demonstration of how these dominant discourses undermine institutional goals of integration (Chapter 1). In K-12 schools, these resettled refugee students are often provided an English-only instructional model even whilst Spanish-speaking students, whose community is older and more powerful, are granted a more flexible model of academic study. The education system implicitly designs ELL pedagogical practices for Spanish speakers; tracking Burmese and other immigrants and refugees into these systems is sub-optimal or even regressive.

\section{(c)}

SDRERIEHISRESERNEDReaders are free to copy, display, and distribute this article, as long as the work is attributed to the author(s) and the Journal of Southeast Asian American Education \& Advancement, it is distributed for non-commercial purposes only, and no alteration or transformation is made in the work. More details of this Creative Commons license are available at http://creativecommons.org/licenses/by-nc-nd/3.0/. All other uses must be approved by the author(s) or JSAAEA.

Journal of Southeast Asian American Education \& Advancement, Vol. 14. Iss. 1. (2019) ISSN: 2153-8999 
As a corrective to this kind of institutional (mis)tracking, Duran proposes that we consider literacy for these populations from the perspective of accumulated literacy that defines literacy as "made up of social-cultural-historical practices learned, collected, modified, and utilized throughout one's life and through different experiences" (p. 17).

This model of accumulated literacy expands literacy beyond school-based and print textfocused one, and allows her, and us, to examine literacy practices that occur in the home and local communities. Furthermore, it encourages us to incorporate numeracy, digital literacy, and nonverbal communication modes as features of literacy that are equally important to print texts (Chapters 5 and 6) and multilingual repertoires that provide resources for meaning-making and literacy development in new languages (Chapters 5 and 7). This social process of accumulating literacy is multidirectional in that learners of all ages and in all language proficiency levels exchange knowledge, engage in hybrid language practices, and become agents of socialization rather than simple receptors of standard literacy practices. Thus, speakers of non-dominant languages, both adults and children, not only are subject to and subscribe to hegemonic linguistic ideologies (e.g., linear development of English proficiency and prioritizing school-based literacy), but also challenge them. In this regard, accumulated literacy perspective takes on characteristics of contestation between dominant and subaltern modes of language, strategies of translanguaging, and the ever shifting ideologies of language within and outside refugee communities.

Duran's book successfully demonstrates this theoretical perspective on literacy development. Here, I discuss three strengths of her work, among others. First, the two-year long ethnography offers various opportunities in examining language practices situated in authentic contexts of language use. As a volunteer, she played multiple roles in three families' homes: a friend, family mentor, tutor and English teacher. As an ethnographic researcher, she collected research data, through observation of homes and neighborhood, copies of artifacts (e.g., books, religious tests, documents, screens of cell phones, laptops, and TV, p. 73), formal interviews, and informal conversations with family members. As a Thai-English bilingual, she brings an emic perspective in analyzing translingual literacy practices among Karenni families. Some interviews were conducted with help of interpreters who served as "language and cultural broker(s)" in that they provided cultural meanings and norms associated with certain words and expressions. In turn, Duran argues, they provided deeper understanding of the Karenni culture and local Karenni community that she herself could not have achieved (p. 76). Her roles in the research setting that carefully balance between insider and outsider positions over the course of two-year data collection afforded a breadth, richness, and authenticity in the collected data. This provided valuable insights into literacy practices situated in social-cultural-historical contexts of these families and lived experiences of three Karenni families.

Second, Duran's work offers stories about unique experiences, challenges, and resources of Karenni families that have not been adequately documented due to their status as speakers of "new, small, and minoritized languages" (p. 25). In Burma/Myanmar, 117 languages are spoken while Burmese is the official language for schooling. Most resettled Karenni families have lived in Thai refugee camps for several years to over a decades, during which they learned Thai and other ethnic languages of Burma (e.g., Shan, Karen) through interactions with Thai and other ethnic groups. Thus, Karenni families learn and speak Karenni and variations of Karenni at homes, Burmese in schools, Thai and other Burmese ethnic languages in Thai refugee camps, and English in schools and at work in the United States. Thus, Karenni individuals' linguistic repertoires vary across families and even within a family depending on migration paths and education backgrounds (e.g., whether they went to school or interacted with ethnic groups other than Karenni). Duran 
shows that this linguistic diversity provides both challenges and resources. As a group, Karenni develop multilingual repertoires that allow transnational and translingual exchange of knowledge, experiences, and skills. Teens develop multilingual proficiency and a desire to learn multiple languages for various functional purposes, such as socialization, entertainment, and school work (p. 105). However, this diversity inevitably makes it hard for the host society to provide targeted language support.

Third, Duran provided thick description and analysis on multimodality in technologymediated literacy practices in which Karenni youth engage (Chapter 6). In our technologymediated world, literacy not only means comprehending and generating print-based texts, but include visual literacy (e.g., generating and comprehending images and symbols) and coordination of multiple modes of communication (e.g., drawing, gesturing, and using a digital device). Her analysis vividly illustrates how resettled Karenni refugee children and adolescents engage in a variety of contextualized literacy practices with their Karenni and non-Karenni friends through video games, mobile phone texts, and social media. While playing video games, children interpreted visual images of the games and read and responded to English phrases used in the video games. When texting, they used abbreviations and colloquial language akin to those of their English-speaking peers. When using social media, they maximized use of multilingual repertoires more freely because computers and online social media platform allowed them to use and switch between different languages and communities (e.g., old friends who they had met in refugee camps, new friends with whom they pursued common hobbies). Through these technologymediated literacy practices, Duran argues, the youth enacted their linguistic creativity, adapted literacy practices to suit the demands of specific contexts, and enacted identities that belong to a certain speech community in each moment of these practices.

After reading this book, I returned to the tension between providing support for marginalized groups and acknowledging strengths and rich resources that they bring to their own lives and the society. The former has a risk of reproducing deficit-oriented narratives that may be counter-productive, whereas the latter may leave ambiguity regarding how to support the marginalized groups. It might actually be deployed by those who would want to deny resources to these populations altogether; if they have not a deficit of language competency but rather an internally generated superabundance of it, why provide support for them at all? Duran does not address this perhaps churlish implication, but does offer some fairly generalized recommendations for teaching of resettled refugee students. She suggests that schools and teachers should allow students to use multilingual repertoires and draw on multimodality and digital literacies by, for instance, using visual aids in instruction, hiring multilingual individuals as translators and teaching aids, providing afterschool English tutoring services for speakers of less commonly taught languages, and applying digital literacies that combine text, sound, image, and contextualized story. These strategies are not limited to literacy development, but other subject areas such as mathematics and science as well. While agreeing with her recommendations, I was left wondering: What are some ways in which teachers might not just encourage students to utilize multilingual repertoires but also more actively leverage them for their new learning? How can visual aids be used in advanced classes, such as high school science in which many concepts are abstract (e.g., force and motion)? How can schools and school districts find qualified bilingual translators and teaching aids and what further training should be provided? What might be some examples of applying digital literacies for literacy development and content area learning?

More fundamentally, how can we empower multilingual learners to be change agents who challenge language ideologies and hierarchies by drawing on their own resources, while also 
providing critical immediate support that they may need? It may involve more than interventions that target these students and the teachers of these students. Larger institutional changes might include incorporating the rich experiences and knowledge of refugee students into the dominant classroom, thus reshaping the classroom into a bridge between native English-speaking students and refugee peers. The refugees' strong social support network, so well documented in Duran's book, opens up a discourse of globalism from below (or across) that is severely lacking in American pedagogical practices, even while making legible the links between refugee families, their particular histories and trajectories, and the formal educational enterprises in which they are enmeshed. Duran's work provides a strong rationale for these approaches and pushes us to pursue ways in which a wide range of literacy is valued and empowers multilingual learners as contributing members of local and school communities.

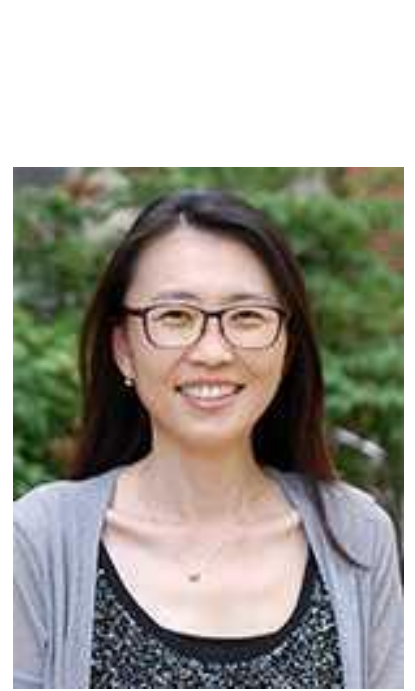

\section{About the Author}

“Resettled Refugee Youths' Stories of Migration, Schooling, and Future: Challenging Dominant Narratives About Refugees," published in The Urban Review, reveals how ten former refugee adolescents author their life stories to challenge disempowering narratives about them. Her ultimate research goal is to leverage those counter-narratives and resources that youth have developed and brought from their unique experiences, knowledge, and disposition as useful assets for new learning. More information about her research is available on her personal website: https://www.chem.purdue.edu/ryu/index.html. 


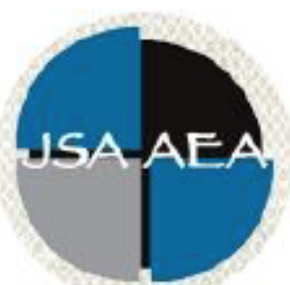

Vol.14 Iss.1 (2019)

\title{
Journal of Southeast Asian American Education and Advancement
}

\author{
WwW.JSAAEA.org
}

\section{Editor}

Dr. Wayne E. Wright

Purdue University

Associate Editors

Dr. Chhany Sak-Humphry

University of Hawaii at Manoa

Dr. Phitsamay Sychitkokhong Uy

University of Massachusetts, Lowell

\author{
Book Review Editor \\ Dr. Vichet Chhuon \\ University of Minnesota \\ Creative Works Editor \\ Bryan Thao Worra \\ Lao Assistance Center \\ Journal Manager \\ Fang Gao \\ Purdue University
}

Editorial Review Board

\author{
Dr. Steve Arounsack \\ California State University, Stanislaus \\ Dr. Sovicheth Boun \\ Salem State University \\ Dr. Virak Chan \\ Purdue University \\ Dr. Loan Dao \\ University of Massachusetts Boston
}

\author{
Dr. Carl L. Bankston III \\ Tulane University \\ Dr. Phala Chea \\ Lowell Public Schools \\ Dr. George Chigas \\ University of Massachusetts, Lowell \\ Dr. Hien Duc Do \\ San Jose State University
}




\author{
Dr. Changming Duan \\ University of Missouri-Kansas City \\ Dr. Sothy Eng \\ Lehigh University \\ Dr. Vincent K. Her \\ University of Wisconsin, Eau Claire \\ Dr. Peter Nien-Chu Kiang \\ University of Massachusetts, Boston \\ Dr. Kevin K. Kumashiro \\ University of Illinois, Chicago \\ Dr. Ha Lam \\ Eastern Mennonite University \\ Dr. Jonathan H. X. Lee \\ San Francisco State University \\ Dr. Monirith Ly \\ Royal University of Phnom Penh \\ Dr. Bic Ngo \\ University of Minnesota \\ Dr. Leakhena Nou \\ California State University, Long Beach \\ Dr. Mark Pfeifer \\ SUNY Institute of Technology \\ Dr. Loan T. Phan \\ University of New Hampshire \\ Dr. Karen Quintiliani \\ California State University, Long Beach \\ Dr. Angela Reyes \\ Hunter College \\ The City University of New York \\ Dr. Fay Shin \\ California State University, Long Beach \\ Dr. Christine Su \\ College of San Mateo \\ Dr. Alisia Tran \\ Arizona State University \\ Dr. Khatharya Um \\ University of California, Berkeley \\ Dr. Kim Tran \\ University of California, Los Angeles, \\ Glendale Community College \\ Dr. Molly Wiebie \\ The University of Texas at Austin
}

Dr. Sophal Ear

Occidental College

Dr. Jeremy Hein

University of Wisconsin, Eau Claire

Dr. Nancy H. Hornberger

University of Pennsylvania

Dr. Peter Tan Keo

New York University

Dr. Yvonne Kwan

San Jose State University

Dr. Ravy Lao

California State University, Los Angeles

Dr. Stacey Lee

University of Wisconsin, Madison

Dr. Sue Needham

California State University, Dominguez Hills

Dr. Max Niedzwiecki

Daylight Consulting Group

Dr. Clara Park

California State University, Northridge

Dr. Giang Pham

University of Massachusetts Amherst

Dr. Malaphone Phommasa

University of Clifornia Santa Barbara

Dr. Kalyani Rai

University of Wisconsin-Milwaukee

Dr. Cathy J. Schlund-Vials

University of Connecticut, Storrs

Dr. Nancy J. Smith-Hefner

Boston University

Dr. Yer J. Thao

Portland State University

Dr. Monica M. Trieu

Purdue University

Dr. Silvy Un

Saint Paul Public Schools

Dr. Linda Trinh Vo

University of California, Irvine

Dr. Yang Sao Xiong

The University of Wisconsin-Madison

Dr. Zha Blong Xiong

University of Minnesota 


\title{
Doctoral Student Editorial Review Board
}

\author{
Linh Dang \\ University of Rochester \\ My-Lan Huynh \\ California State University East Bay \\ Hoa Nha Nguyen \\ Boston College \\ Thien-Huong Ninh \\ University of Southern California \\ Krissyvan Truong \\ Claremont Graduate University \\ Melissa Vang \\ San Diego State University \\ Claremont Graduate University
}

\author{
Annie BichLoan Duong \\ San Joaquin County Office of Education \\ Dung Minh Mao \\ University of Minnesota \\ Khoi Nguyen \\ George Mason University \\ Linda Marie Pheng \\ University of Wisconsin-Madison \\ Mai Vang \\ University of Massachusetts Boston \\ Soua Xiong \\ San Diego State University \\ Claremont Graduate University
}

